\title{
Formation and disintegration of virions in lymphocystis cells of plaice Pleuronectes platessa
}

\author{
N. Peters, W. Schmidt \\ Zoologisches Institut und Zoologisches Museum der Universität Hamburg, Martin-Luther-King-Platz 3, \\ D-20146 Hamburg, Germany
}

\begin{abstract}
In lymphocystis cells of plaice, conspicuous anomalies occur during virus propagation Ball-shaped masses of capsid material are frequently deposited within the viral inclusion body. Newly formed virions may later undergo disintegration. Membrane-bound club-shaped bodies with a partially crystalline content are observed which are possibly of lysosomal character and might play a role in the disintegration of virions.
\end{abstract}

KEY WORDS: Lymphocystis · Virion disintegration Pleuronectes platessa

\section{INTRODUCTION}

The fish lymphocystis virus (family Iridoviridae) transforms connective tissue cells (fibroblasts) of the skin and inner organs to millimetre-sized cells with correspondingly enlarged, strongly lobulated nuclei. During enlargement of the cells, a Feulgen-positive inclusion body of viral DNA forms in the cytoplasm. The divided, frequently web-like inclusion body occupies the major part of the cytoplasm of the enlarged cells. On its surface, masses of isosahedral virions are formed with diameters (depending on the host species) of 120 to $380 \mathrm{~nm}$. The lymphocystis cells, which are by then huge, round, and filled with virus material, are held together by a coarse mucopolysaccharide capsule which is exuded from fjord-like invaginations of the plasmalemma (Anders 1984, Wolf 1984, Flügel 1985).

At mid-range electron-optical resolution, the lymphocystis virions reveal a dark, central nucleoid and an icosahedral capsid which is covered by a fine, filamentous coating (regarding the fine structure of virions in connection with biochemical data, see Berthiaume et al. 1984, Flügel 1985). Virion formation at the surface of the inclusion body occurs as follows (Schacht 1988): first open capsids are formed against the viral DNA and are then apparently supplied with the material necessary for the nucleoid before they are finally closed. A central condensation of the nucleoid does not occur until after the capsid has closed, as can be concluded from the occurrence of partially to completely closed capsids with evenly dispersed DNA material (cf. Fig. 1).

In mature lymphocystis cells, condensation of the viral DNA and compartmentalization of the inclusion body in loops or patches can be observed, whereby new virions are constantly forming. At the same time, aging of the cells is also indicated by the fact that the endoplasmic reticulum, which is primarily situated near the nucleus, appears vacuolated and that the mitochondria, which are concentrated in the cortical cytoplasm, degenerate, sometimes forming myelin figures. Finally, nucleus and plasmalemma disintegrate. At this stage, the cell capsule normally tears open, and a mixture of virions, remains of the inclusion body, and cell debris flow out (Peters et al. 1981).

This description of lymphocystis is also basically true for plaice. However, in this study some differences and additional features of lymphocystis in plaice are reported.

\section{MATERIALS AND METHODS}

A total of 12 North Sea plaice (German Bight to Dogger Bank) afflicted by lymphocystis were examined, whereby lymphocystis cells of a third to final size were 
included. Skin samples of 1 to $2 \mathrm{~mm}$ side length were fixed in glutaraldehyde $\left(5 \%, 6 \mathrm{~h}\right.$ at $\left.4{ }^{\circ} \mathrm{C}\right)$, washed in phosphate buffer $(0.2 \mathrm{M}, \mathrm{pH} 7.28)$, postfixed in osmium tetroxide $\left(1 \%, 2 \mathrm{~h}\right.$ at $\left.4{ }^{\circ} \mathrm{C}\right)$, washed again in phosphate buffer, dehydrated in ethanol 15 min each in 30 , 50 and $70 \%$ at $4{ }^{\circ} \mathrm{C}$ ), and embedded in Epon. Sections of $1 \mu \mathrm{m}$ thickness were stained with toluidine blue for light microscopy. Additional semithin sections were subjected to the Feulgen or the Millon reaction (Baker 1956) after having been removed from the embedding material (Epon) with sodium methylate in methanol. For transmission electron microscopy, ultrathin sections of approximately $80 \mathrm{~nm}$ thickness were contrasted with uranylacetate and lead citrate. For autoradiographic analysis, Iymphocystis cells were incubated with ${ }^{3} \mathrm{H}$-marked thymidine $\left(25 \mu \mathrm{Ci} \mathrm{ml}{ }^{-1}\right)$ in Hanks' balanced salt solution. After exposure for $5 \mathrm{~h}$ with periodic aeration, the samples were carefully rinsed with an inactive thymidine solution and then fixed and embedded as described above. Semithin sections were coated with Kodak AR 10 stripping film and developed with Kodak D 19 after

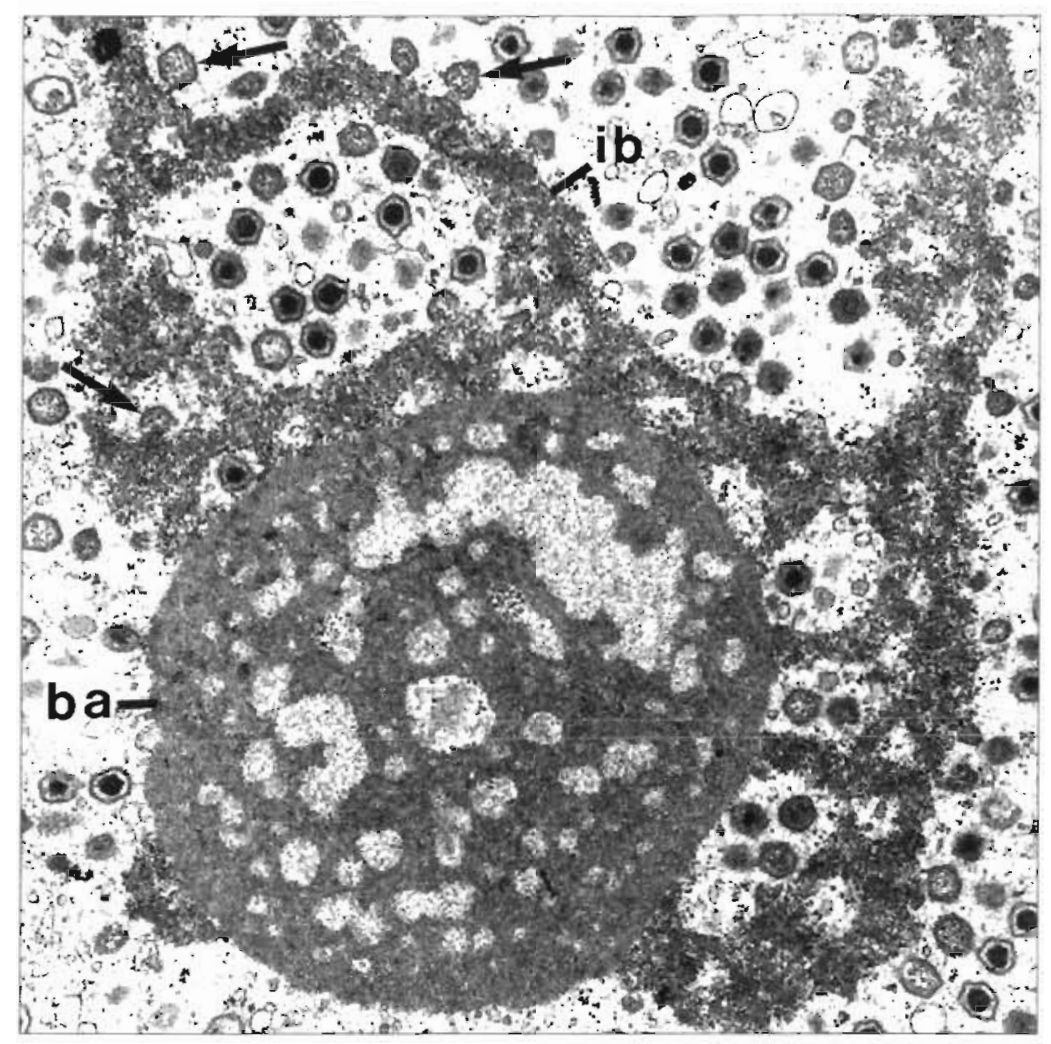

Fig. 1 Pleuronectes platessa. Partially condensed viral DNA of the inclusion body (ib) in the cytoplasm of a mature plaice lymphocystis cell, associated with a large ball of capsid material (ba). Various stages of virion formation are on the surface of the DNA (arrows) $\times 20000$ exposure times of 6 or $12 \mathrm{wk}$ at $4^{\circ} \mathrm{C}$. After acidification with $0.1 \%$ acetic acid (pH 2.5 to 3 ), the specimens were stained through the film coating with toluidine blue solution (with sodium bicarbonate adjusted to $\mathrm{pH} 11.0$ to 11.4 ).

\section{RESULTS}

\section{Irregularities in virus propagation}

In contrast to observations on other fish species, in plaice lymphocystis cells, balls of fine-grained material, somewhat foamy-looking, are frequently associated with the inclusion body (Fig. 1). These balls either are dispersed in the free spaces of the inclusion body, are in contact with the DNA material or are completely surrounded by it. They are usually between 1 and $5 \mu \mathrm{m}$ in diameter so that they are easily visible under the light microscope. Contrary to the inclusion body itself, they are Feulgen-negative. Instead, they can be stained darker than their surroundings by means of the Millon reaction to protein.

The following observation clarified the nature of these balls: in 2 mature plaice lymphocystis cells the inclusion body was partitioned into small compartments containing 2 substances which could be clearly differentiated from one another (Fig. 2a, b). At the surface of these inclusion body compartments, formation of virions as a sort of budding was observed, whereby the nucleoids of the virions were formed of particularly electron-dense material and the capsids of moderately electron-dense, medium grey substance. The electron-dense material is apparently tightly condensed DNA, but the medium grey substance appears to be capsid substance. In some of the inclusion body compartments, the capsid material collected into small balls corresponding in form and structure to the freely dispersed balls described above.

Live, mature plaice lymphocystis cells were incubated with ${ }^{3} \mathrm{H}$-thymidine immediately after removal. In the semithin-section autoradiogram, the parts of the inclusion body containing DNA are clearly marked by an accumulation of silver grains (Fig. 3). In contrast, the separate balls are not marked. This result is in agreement with the observations on the nature of the balls as capsid material. At the same time, it indicates that the viral DNA is still replicating at this stage in at least a partially condensed form. 


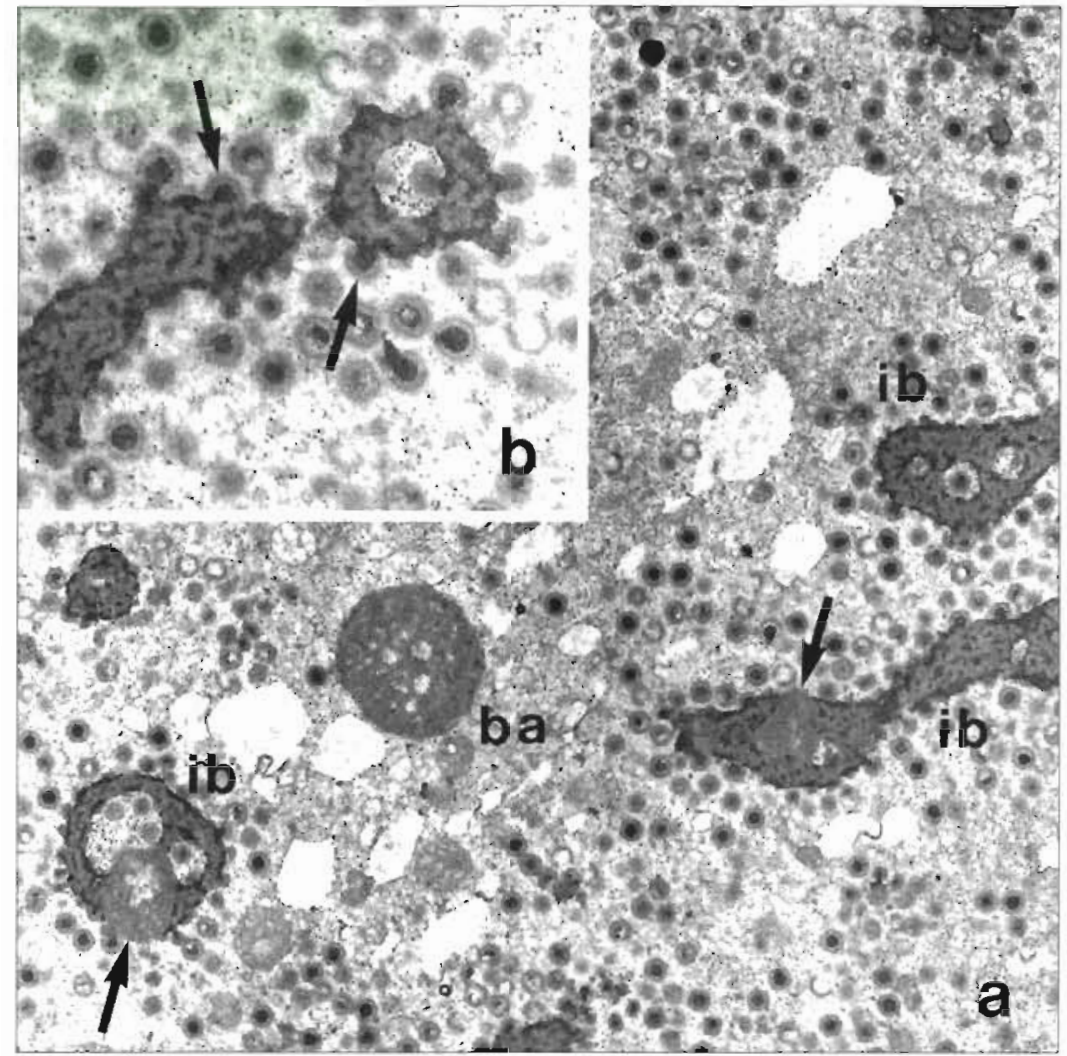

Fig. 2. Pleuronectes platessa. Several small parts of the inclusion body (1b) in the cytoplasm of a mature plaice lymphocystıs cell Strongly condensed viral DNA (dark) and capsid material (grey) are intermixed (a) Smaller, integrated balls (arrows) as well as larger, free lying balls of capsid materlal (ba) can be recognized. $\times 10000$. (b) The new formation of vinons from varal DNA. (dark) and capsid material (grey) has a bud-like appearance (arrows) $\times 20000$ such balls is then a result of the continuous deposition of further swollen capsids

We consider a reverse order for this development to be highly unlikely It would mean that the foamy balls of capsid material first separate into swollen, rounded and then icosahedron-shaped capsids, in which nucleoıds finally develop. No DNA, which would be the raw material for nucleolds, is evident by staining or autoradiographic methods in the foamy balls. The conspicuous lucence inside the empty capsids also casts doubt on the existence of viral DNA which could condense to nucleords.

\section{Club-shaped bodies with crystalloid structure}

Round, oval to club-shaped bodies enclosed by membranes, approximately the size of the mitochondria, were observed in plaice lymphocystus cells (Fig 5) Inside, they are divided into 2 parts, a light, elongated. cross-ridged central part and a dark, amorphous part. which forms the club swelling The cross-ridging is indicative of a crystalloid structure. The round, oval to

\section{Disintegration of virions}

In 3 plaice (out of a total of 12) we observed overmature lymphocystis cells. These no longer contain any specifically DNA-stainable remains of the inclusion body. However, the round balls of capsid matenal are conspicuous. In addition, there are smmlar balls, which can be distinguished from those described particularly by their irregular surfaces, and which, moreover, have a foamy appearance (Fig. 4a) Their substance appears less grainy than amorphous. Their formation and their nature can be denved from the following:

In the overmature lymphocystis cells, numerous virions are visible, the nucleoids of which are more or less destroyed by 'moth holes'. It is unlikely that these represent a loosening of the DNA: more likely, they represent a separation of the DNA material, which is indicated by the conspicuous lucence at these locations. The empty capsids then swell and aggregate to form foamy conglomerates. The irregular surface of

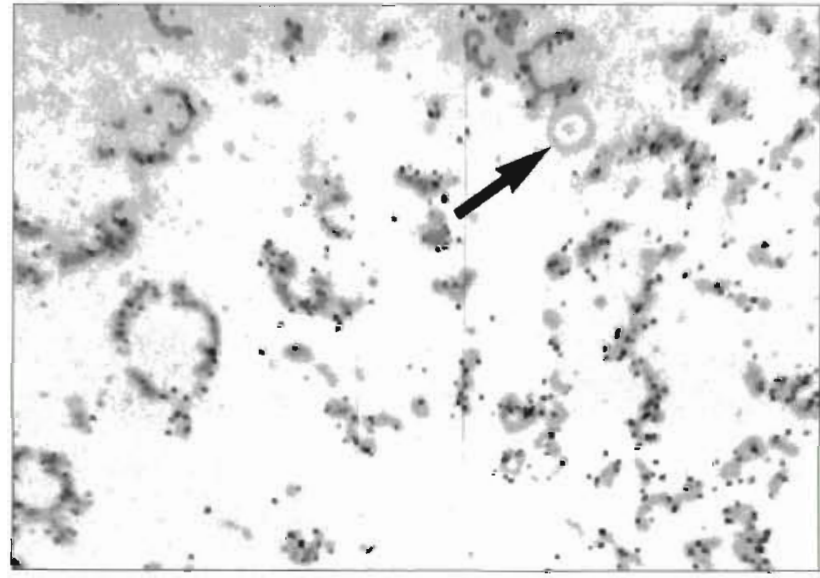

Fig 3 Pleuronectes platessa Semuthın-sectıon autoradıogram of the inclusion body in a mature place lymphocystis cell after incubation with ${ }^{3} \mathrm{H}$-thymidine. The silver graıns are accumulated over the dark-appearing viral DNA of the inclusion body. A separate ball of capsid material (arrow) is not marked $\times 680$ 

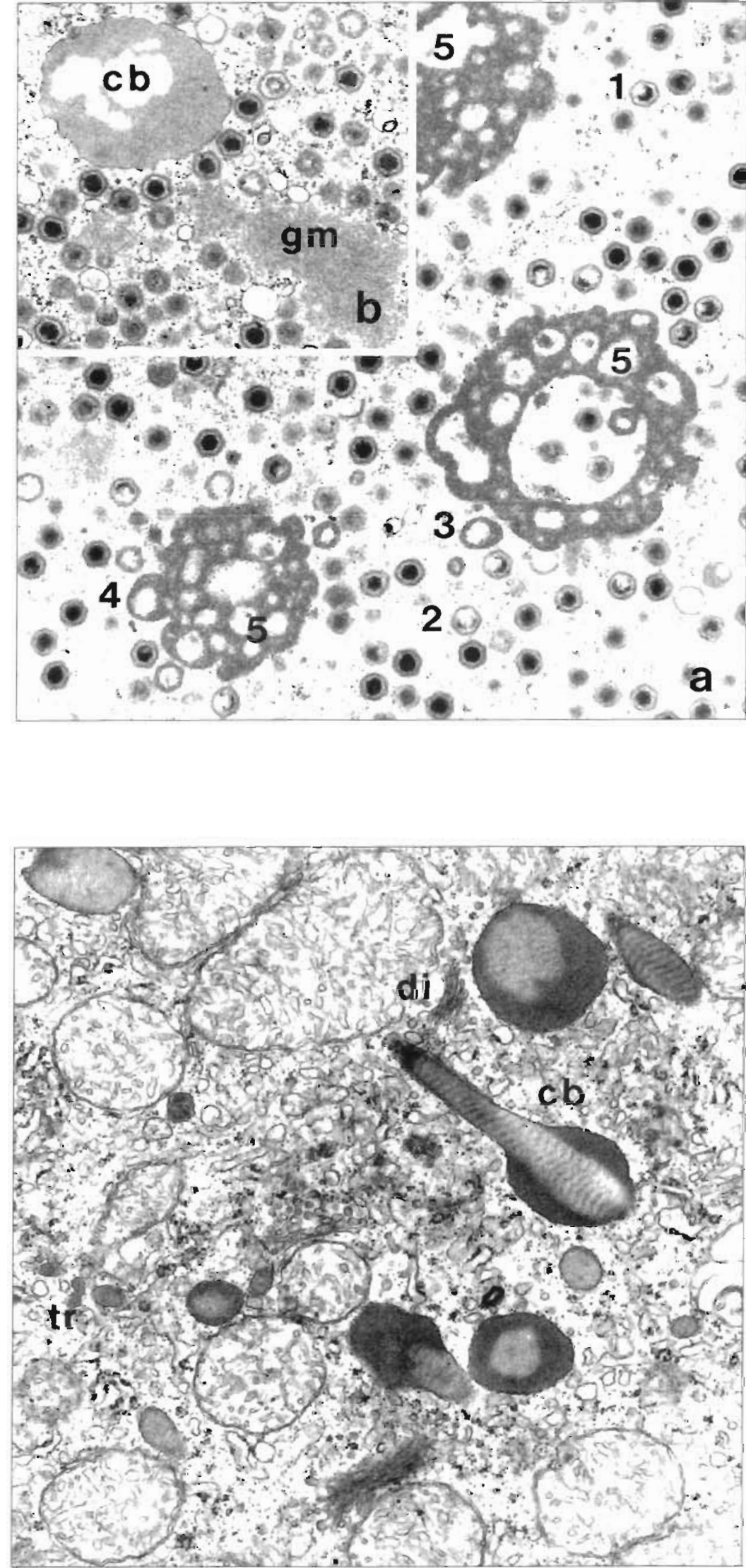

Fig 4. Pleuronectes platessa. Disintegration of virions in an overmature plaice lymphocystis cell. (a) Increasing dissolution of the virion nucleoids $(1,2)$, swelling, empty virion capsid (3), swollen virion capsid in the process of aggregation (4), conglomerate of aggregated virion capsids (5). $\times 20000$. (b) Swelling and breaking up 'clubshaped' body (cb) in an overmature plaice lymphocystis cell; adjacent is flakey, fine-grained material $(\mathrm{gm}) \times 20000$

elongated bodies with alternating proportions of both parts can be seen as representing various sections of the club figure, but more irregular forms of these bodies are also observed.

At the same time, large numbers of dictyosomes, which are normally seldom seen in lymphocystis cells, also occur. Along with the Golgi vesicles and the club-shaped bodies, one finds vesicles of all intermediate sizes with at first light grey or dark grey contents, as well as larger ones with the contents divided into 2 parts, all of which can be interpreted to be transitional vesicles. Apparently, the subdivided vesicles may occur through fusion of vesicles with different contents, whereby the club shape is caused by the subsequent 'crystallizatıon' of the light material. In other lymphocystis cells of plaice, light and dark vesicles remain separate, retain their round to oval shape and attain only about half the size of the club-shaped bodies. In these cases no 'crystallization' occurs in the light vesicles.

Dictyosomes and Golgi vesicles, as well as intact club-shaped bodies, are mainly found in immature and not fully grown lymphocystis cells. In contrast, in the mature to overmature cells with slgns of disintegration of virions, the membrane of the club-shaped bodies is frequently broken down and the contents are more or less swollen, whereby the crystalloid structure gradually fades (Fig 4b).

Fig. 5. Pleuronectes platessa. Club-shaped bodies (cb) in an immature plaice lymphocystis celli adjacent are dictyosomes with Golgi vesicles (di), as well. as transition vesıcles (tr) $\times 20000$ 
In such mature to overmature lymphocystis cells of plaice, instead of inclusion bodies we repeatedly observed flakes of fine-grained material dispersed throughout the cytoplasm (Fig. 4b). Occasionally these flakes contain still loosely dispersed filamentous material of the viral DNA type. This is probably the remains of the inclusion body after dissolution of the DNA, which is in agreement with the spatial distribution of the flakes. The flakes appear to be a further manifestation of capsid protein, which is normally optically masked by the DNA material.

\section{DISCUSSION}

In lymphocystis cells of fish in general, the DNA material from which the nucleoids of the forming virions originate can be represented with light and electron microscopy as an inclusion body. The material from which the capsids originate appears beforehand to be so thinly dispersed or so masked by the viral DNA that these substances only become visible when capsids are formed. In the plaice lymphocystis cells separation of ball-like capsid material frequently occurs, whereby this material is no longer involved in the formation of virion capsids. Occasionally, plaice lymphocystis cells contain parts of inclusion bodies in which DNA material and capside material clearly intermingle, both materials contributing to the formation of the virions in a kind of budding process.

A further unusual finding was the disintegration of newly formed virions in overmature lymphocystis cells. It seems plausible that the first manifestation, the dissolution of the virion nucleoids (as well as of the remaining free viral DNA), is an effect of nucleases, while the capsids are denatured by proteolytic enzymes, this being at first optically inconspicuous and then followed by swelling and conglomeration of the swollen capsids. The origin of such enzymes may be lysosomes represented by the club-shaped bodies. Their bursting seems to occur simultaneously with the disintegration of the virions.

The lymphocystis virus can be considered particularly successful, in that it stimulates its host cell to gigantic growth, in the process engaging the cells in

Editorial responsibility: Managing Editor the massive production of virions. On the other hand, the separation of unused capsid material, the disintegration of virions and the dissolution of free viral DNA does not make sense as a viral strategy or would appear even to go against it. These contradictions lead to the conclusion that the lymphocystis virus has not yet been able to optimally adapt to the plaice as a host. The variability in the formation of the virions as well as the variability in the structure of the 'lysosomal' bodies also support this. In the lymphocystis cells of dab Limanda limanda, which is closely related to plaice (Norman 1934, Sakamoto 1984), but which is afflicted with another strain of the lymphocystis virus (Darai et al. 1983), no such irregularities are found. Neither the disintegration of virions nor the formation of round, oval to club-shaped bodies of possible lysosomal character is observed (Peters et al. 1981, Schacht 1988).

\section{LITERATURE CITED}

Anders K (1984) Die Lymphocystis-Krankheit der Fische Verlag Heino Möller, Kiel

Baker JR (1956) The histochemical recognition of phenols, especially tyrosine. Q J microsc Sci 97:161-164

Berthiaume L, Alain R, Robin J (1984) Morphology and ultrastructure of lymphocystis disease virus, a fish iridovirus grown in tissue culture. Virology 135:10-19

Darai G. Anders $K$, Koch $H G$, Delius $H$, Gelderblom $H$, Samalecos C, Flügel RM (1983) Analysis of the genome of fish lymphocystis disease virus isolated directly from epidermal tumours of Pleuronectes. Virology 126:466-479

Flügel RM (1985) Lymphocystis disease virus. Microbiol Immunol 116:133-150

Norman JR (1934) A systematic monograph of the flatfishes (Heterosomata), Vol 1, Psettodidae, Bothidae, Pleuronectidae. Johnson Reprint Company Ltd, London

Peters N, Stich HF, Kranz H (1981) The relationship between lymphocystis disease and $X$-cell papillomatosis in flatfish. In: Dawe CJ et al (eds) Phyletic approaches to cancer. Japanese Scientific Society Press, Tokyo, p 111-121

Sakamoto K (1984) Interrelationships of the family Pleuronectidae (Pisces: Pleuronectiformes). Mem Fac Fish Hokkaido Univ 31:95-215

Schacht V (1988) Untersuchungen zur Lymphocystiskrankheit in inneren Organen der Kliesche (Limanda limanda, L.) Diplomarbeit, Universität Hamburg

Wolf K (1984) Diseases caused by microorganisms. Agents: Virales. In: Kinne $O$ (ed) Diseases of marine animals, Vol IV, Part 1: Introduction, Pisces. Biologische Anstalt Helgoland, Hamburg, p 17-47

Manuscript first received: June 10, 1994

Revised version accepted: August 15, 1994 